\title{
Pavel Blažek
}

\section{Bartoloměj z Brugg o relevanci praktické filosofie}

Ptáme-li se po roli filosofie a filosofư v předmoderních společnostech, jak zní podtitul dnešního kolokvia, je zajisté vhodné začít otázkou, jak chápali a definovali svou společensko-politickou roli samotní „předmoderní“ filosofové.

Ve svém diskusním př́spěvku bych chtěl představit úvahy o společensko-politické relevanci praktické filosofie (a tím reflexi vlastní „společenské role") jednoho málo známého středověkého filosofa z přelomu 13. a 14. století, Bartoloměje z Brugg.

V galerii středověkých filosofů patří Bartoloměj z Brugg poněkud neprávem - spíše k auctores minores. Působil na pařížské artistické fakultě v prvním desetiletí 14. století jako magister artium. Byl to typický reprezentant onoho nového typu profesionálního filosofa, který se zrodil ve 2. polovině 13. století právě zde, na pařížské facultas artium v procesu její institucionální emancipace od fakulty teologické -, a který se vyznačoval tím, že chápal svoji filosofickou profesi jako svébytnou a odlišnou od profese teologa. Proslul zejména jako autor drobných logickofilosofických pojednání - tzv. sophismat - a komentářů k méně známým aristotelským a pseudo-aristotelským spisům, z nichž dosud jen část vyšla tiskem. Vedle jediného dochovaného středověkého komentáře $\mathrm{k}$ Aristotelovu spisku De inundatione Nili, zabývajícího se důvody každoročních záplav Nilu, napsal například rovněž jediný středověký komentář k Aristotelově Poetice, či spíše k její averroovské parafrázi.

Pro nás je důležité především to, že byl jedním z nejvýznamnějších reprezentantů středověké, aristotelsky orientované „,praktické“ či morální 
filosofie (philosophia practica vel moralis), tak jak byla od svého vzniku (či spíše obnovení) ve 13. století pěstována především na středověkých artistických fakultách. Podle schématu filosofických disciplín- v jádru aristotelského -, které středověk recipoval skrze Boethia, Cassiodora a arabské autory a které ovlivnilo také kurikulum pařížské artistické fakulty, tvořila philosophia practica protiklad k teoretické či spekulativní filosofii a sestávala ze tří dílčích disciplín: z etiky či monastiky, obecně chápané jako morálně-filosofická nauka o správném jednání jednotlivce, ekonomiky jako morálně-filosofické nauky o domácnosti a konečně politiky jako morálněfilosofické nauky o obci. Tyto tři disciplíny byly od 30 let. 13. století vyučovány a pěstovány prostřednictvím komentářò ke třem nově objeveným aristotelským spisům, které byly postupně těmto třem disciplínám přiřazeny jako jejich základní texty: k Etice Nikomachově, k pseudo-aristotelské Ekonomice a k Aristotelově Politice.

Bartoloměj z Brugg je autorem nejvlivnějšího a nejobsáhlejšího středověkého komentáře k pseudo-aristotelské Ekonomice, a tím jednoho z nejvýznamnějších středověkých spisů ke středověké prakticko-filosofické nauce o domácnosti. Komentář vznikl v roce 1309 a jeho význam spočívá jak v jeho vlivu - téměř všechny pozdější středověké komentáře k Ekonomice z něj vycházejí -, tak v jeho filosofickém obsahu. Bartoloměj v něm totiž nepodává pouhý výklad pseudo-aristotelského textu, ale snaží se o jeho hlubší filosofickou reflexi a o filosofickou aktualizaci v něm obsažených myšlenek a jejich aplikaci na různé sociální otázky problémy své doby. Tak se např́ílad jako první pokouší prokázat - v rozporu $\mathrm{s}$ dosavadní tradicí a v rozporu s literou své pseudo-aristotelské předlohy -, že ekonomika není pouhou praktickou dovedností, ars, ale že je aristotelskou „vědou“, scientia, v plném slova smyslu. Mezi sociálněfilosofické problémy, kterými se zabývá, patří například problém vztahu a postavení muže a ženy v manželství i ve společnosti, otázky týkající se správy domácnosti, ale také obecnější otázky vztahu domácnosti a obce. Navzdory svému vlivu i filosofické zajímavosti nebyl Bartolomějův 
komentár̆ dosud kriticky vydán a je zatím dostupný pouze ve středověkých rukopisech.

Jak jsem již naznačil, tím, co činí tento komentář zajímavým pro téma dnešního kolokvia, je, že se v něm Bartoloměj snaží reflektovat význam praktické filosofie pro společensko-politickou praxi. Konkrétně mu jde o to určit, jaký je vztah a přínos filosofické ekonomiky pro řízení domácnosti, přičemž zároveň formuluje svou představu o vztahu a př́nosu politiky pro řízení obce. Bartolomějova pozice vyplývá jednak z jeho celkového pojetí praktické filosofie, kterou definuje jako tu část filosofie, jejíž cílem je korigovat lidské jednání, a jednak z výše zmíněné skutečnosti, že na rozdíl od samotného Aristotela a od některých jiných středověkých autorů chápe ekonomiku, což platí také pro politiku, nikoliv pouze jako ars, ale jako plnohodnotnou aristotelskou scientia, která zprostředkovává poznání příčin věcí (ratio propter quid) a která se řídí vědeckými kritérii formulovanými Aristotelem ve Druhých Analytikách a jinde.

Hlavním místem, kde se Bartoloměj ve svém komentáři zabývá relevancí ekonomiky pro řízení domácnosti (a s tím zároveň i politiky pro ř́zení obce), je kvestie: Utrum yconomica sit scientia homini neccessaria, zda je ekonomika vědou pro člověka nezbytnou?

Jeho odpověd' je jednoznačně kladná: Pro Bartoloměje sice znalost ekonomiky není absolutně (simpliciter) nezbytná pro řízení domácnosti ostatně mnohé domácnosti jsou řízeny lidmi bez znalosti této filosofické disciplíny. Je však nezbytná $\mathrm{k}$ tomu, aby domácnost byla ř́zena dokonalým způsobem (ad regimen perfectum domus).

Bez znalosti ekonomiky se totiž podle Bartoloměje hospodár snadno dopouští při řízení domácnosti chyb (contingit error in regimine domus). Avšak i v případě, že se chyb nedopouští, protože řídí domácnost na základě své zkušenosti (experientia), nečiní tak dokonalým způsobem, protože mu chybí znalost rozumových přčcin jeho jednání (non habebit 
rationem propter quid sui operis). Bartoloměj dokonce tvrdí, že se jednání takového člověka podobá jednání „neoduševnělých“, rozuměj rozumovou duší či rozumem nenadaných tvorů (agit velut inanimatum) - na mysli zde má nejspíše zvířata -, kteří sice nějakým způsobem jednají, nedokáží však své jednání racionálně reflektovat.

To, co platí o scientia oeconomica ve vztahu k řízení domácnosti, platí podle Bartoloměje analogicky také o scientia politica ve vztahu k řízení obce: „Znalost politiky je nezbytná $k$ dokonalému řizení obce. Pokud ji člověk nemá, totiž často chybuje, neni-li ve vládnutí zkušený, ale $i$ když je zkušený, nevládne dokononale - nemá totiž znalost přičin (ratio propter quid) svého jednáni"“

Kdybychom se měli pokusit vyjádřit Bartolomějovu pozici moderní terminologií, mohli bychom ji souhrnně reformulovat takto: Politická i sociální filosofie (nebot' pod tento termín lze nejspíše zahrnout oblast, kterou se zabývala klasická ekonomika jako nauka o domácnosti) jsou pro zdařilou politickou a společenskou praxi naprosto nezbytné, protože poskytují politikům a jiným společenským aktérům nezbytný racionální návod k úspěšnému jednání.

Je zřejmé, že Bartolomějův koncept vztahu praktické filosofie a politicko-společenské praxe v sobě nese velmi vysoké mínění o roli filosofů ve společnosti (a tím o Bartolomějově vlastní roli praktického filosofa). Je to jen další doklad onoho přesvědčení o společenské výjimečnosti a nadřazenosti filosofư, tak příznačného právě pro „nové““ profesionální filosofy působící na tehdejší pařížské artistické fakultě, jak v minulých letech ukázal naprŕíklad Alain de Libera (srov. Alain de Libera, Penser au Moyen Age, Paris 1991).

Aniž zde mohu tento bod důkladněji rozvíjet, chtěl bych skončit konstatováním, že Bartolomějovo poněkud exaltované přesvědčení o relevanci praktické filosofie pro společenskou a politickou praxi zůstalo ve své době pouhým přáním. Roli politicky a sociálně relevantního vědění 


\section{AIOH IP II. 3}

totiž ve vrcholně a pozdně středověké christianitas nesehrávala (či sehrávala jen v omezené míře) filosofie, nýbrž teologie a ještě více církevní a římské právo. 